\title{
Understanding recent trends in Swiss ambulatory care utilization when out-of-pocket payment is minimal
}

\author{
Submitted: 20 September 2005 \\ Accepted: 2 June 2006
}

Summary

Objective: To examine trends in ambulatory care utilization when individuals face almost no financial barriers to health care.

Methods: Observational study of insurance data. Adults with minimal deductible were included. Ambulatory care visits and costs were measured from 1997 to 2002.

Results: Mean ambulatory care costs/insuree increased from 1292.- to 1790.- CHF, corresponding to higher increases in drug costs $(+61.7 \%)$ than services costs $(+24.3 \%)$. The proportion of visits to generalists decreased while those to hospital outpatient services increased.

Conclusions: In a demographically stable population of insurees, increases in ambulatory care costs were due neither to growth in physicians' visits nor to increasing physicians' fees per act, but to what was included in or prescribed during the visits.

Keywords: Ambulatory care - Utilization - Health care costs - Trends

Between 1997 and 2002, health care costs in Switzerland increased from 38670 to 47959 millions CHF (Office fédéral de la santé publique 2004). This steady rise in annual health care costs brings Switzerland to rank second, after the United States, in terms of health spending (Organization for Economic Co-operation and Development (OECD) 2004).

Several explanations to rising health expenditures were explored by Bodenheimer in a series of articles (Bodenheimer 2005a; Bodenheimer 2005b; Bodenheimer 2005c), including factors external to the health care system such as aging of the population or the state of the overall economy, technologic innovation and the market power of health care providers. He concluded that rising health care costs in the United States were not strongly associated with the aging demographic trend of the population, but that the market power of healthcare providers, and even more technologic advances, were key drivers of this growth. In Switzerland, politicians explicitly attributed part of the rise in health spending to the increase in physicians' density, which reached 1.96/1000 inhabitants in 2002, and passed a federal urgent act forbidding the opening of new private practices in July 2002. Patients' expectations and demand for health care may possibly lead to increased utilization (Domenighetti \& Pipitone 2002), especially if health care access is facilitated by a regular rise in physicians' density. We hypothesized that persons most likely to intensify their health care utilization would be those whose health insurance deductible was minimal, therefore guarantying almost no financial barriers to health care. We were primarily interested in looking whether these insurees modified their health care utilization over time and consulted more as medical density increased. Of particular interest was the pattern of the rise in ambulatory care costs, namely whether insurees used more ambulatory care in terms of number of medical visits or of visits intensity (more prescribed services and/or drugs), and whether the proportion of ambulatory care visits to generalists, internists, other specialists and hospital outpatients services changed over time. We hence conducted an observational study of Swiss insurance data to evaluate time trends in ambulatory care over the 1997-2002 period.

\section{Methods}

Setting and Study Population

In Switzerland, a country of 7.3 million inhabitants, ambulatory care is mainly provided by independent private practi- 
tioners and outpatient services located in hospitals, paid on a fee-for-service basis. Since the new Health Insurance Law came into force in January 1996, greater social solidarity and universal access to health care has been achieved through compulsory basic health insurance coverage that includes a comprehensive package of health benefits identical for all insurees (Polikowski \& Santos-Eggimann 2002). By law, a finite set of contracts vary essentially by the level of annual deductible, with higher deductibles being associated with lower monthly premiums. Beyond the selected deductible, all insurees contribute to $10 \%$ of ambulatory costs, up to an annual ceiling.

Anonymous health insurance data were obtained from one of the four largest Swiss health insurance companies, from 1997 to 2002 , time period for which data were available. Included were all adults aged $\geq 19$ years having chosen a minimal deductible (150.- Swiss francs in 1997, 230.- in 1998-2002). Excluded were insurees with HMO contracts (selected by $1.5 \%-3.2 \%$ each year) and those not insured during the whole fiscal year (approximately $1 \%$ of insurees). Insurees with higher deductibles health plans (29-33\% of insurees) were not included in the dataset since they faced additional financial barriers to health care access.

\section{Measures}

Ambulatory care utilization dimensions of main interest were ambulatory care visits and costs. Insurees who had total ambulatory care costs below the annual deductible or who did not send their bills to the health plan were counted as having neither ambulatory care costs nor visits.

\section{Ambulatory care visits}

Ambulatory care visits were counted only if the encounter included a contact with a physician, and categorized as visits to: generalists, internists, other specialists and any physician from hospital outpatient services (specialty unknown).

\section{Ambulatory care costs}

Total ambulatory care costs were defined as all costs associated with ambulatory or outpatient medical consultations, including laboratory, radiology and other complementary exams and ambulatory prescribed drugs. They were divided into services costs and drug costs, the latter incorporating only the costs of prescribed drugs. Services and drug costs could not be divided into smaller components such as laboratory or radiology costs, for example. For each year, the mean costs per ambulatory care visit was calculated by dividing the total ambulatory care costs by the total number of ambulatory care visits.

Costs billed by health professionals were expressed in Swiss francs. Because medical care inflation rate was low (yearly variations approximated $0.5 \%$ between 1997 to 2002), we did not adjust costs for inflation.

\section{Other variables}

Demographic characteristics (age and sex) as well as selected events (hospitalization and death during the current year) were obtained from the health plan administrative data. Socio-economic variables and comorbidities were not available.

\section{Statistical Analysis}

Based on yearly cross-sectional analysis, simple descriptive statistics were used. We chose not to report $P$-values describing ambulatory care utilization over time because the large number of patients included result in even minor differences being statistically significant. We rather emphasized possible relevance of the results.

\section{Results}

Demographics of the study population did not change markedly during the observed period. The proportion of female insurees slightly increased, from $55.8 \%$ in 1997 to $57.0 \%$ in 2002. Mean age fluctuated between 48.3y (19.6 SD) and 49.5y (19.8 SD), and death rates varied from 140/10000 (1998) to 151/10000 (1997 and 2002). The proportion of insurees having had any health care cost (ambulatory and/or hospital) regularly increased, from $74.7 \%$ (1997) to $80.0 \%$ (2002), and the proportion of any hospital admission remained pretty stable (Tab. 1).

\section{Trends in ambulatory care visits}

The yearly mean number of ambulatory care visits per insuree increased slightly throughout the years, as the proportion of insurees having had no visits during the year declined while the proportion of those with seven or more visits increased. Also, the distribution of ambulatory care visits by type of providers showed a small change with fewer visits to generalists (from $45.8 \%$ in 1997 to $44.1 \%$ in 2002) but more consultations to hospital outpatient services (from $6.3 \%$ in 1997 to $8.7 \%$ in 2002). The proportion of visits to internists and specialists remained constant (Tab. 1).

\section{Trends in ambulatory care costs}

Mean total ambulatory care costs per insuree increased from 1292.- (1997) to 1790 .- CHF $(2002,+38.5 \%)$. Graphic 1 displays this rise, mostly reflecting an increase in drug costs $(+61.7 \%)$ and to a lesser extent an increase in services costs $(+24.3 \%)$. It also shows the proportional annual growth in those 2 components, as well as the regular augmentation in mean cost per ambulatory care visit. 
Table 1 Description and evolution of health care utilization, from 1997 to 2002

\begin{tabular}{|c|c|c|c|c|c|c|}
\hline & 1997 & 1998 & 1999 & 2000 & 2001 & 2002 \\
\hline & $(n=447627)$ & $(n=460029)$ & $(n=471226)$ & $(n=462258)$ & $(n=437425)$ & $(n=414094)$ \\
\hline \multicolumn{7}{|l|}{$\begin{array}{l}\text { Any health care cost during current year } \\
\text { (above the minimal deductible, hospital or }\end{array}$} \\
\hline Hospitalized during current year, \% & 14.1 & 14.1 & 14.2 & 16.6 & 14.5 & 14.8 \\
\hline $\begin{array}{l}\text { Yearly mean number of ambulatory care visits / } \\
\text { insuree }\end{array}$ & 6.5 & 6.5 & 6.4 & 6.6 & 6.8 & 6.9 \\
\hline \multicolumn{7}{|l|}{ Number of visits (\%): } \\
\hline 0 & 25.3 & 24.8 & 23.7 & 22.9 & 22.2 & 21.7 \\
\hline $1-2$ & 16.3 & 16.4 & 17.2 & 16.9 & 16.5 & 16.6 \\
\hline $3-4$ & 13.2 & 13.2 & 13.9 & 13.8 & 13.5 & 13.6 \\
\hline $5-6$ & 10.4 & 10.4 & 10.7 & 10.7 & 10.9 & 10.7 \\
\hline $7-11$ & 16.6 & 16.9 & 17.3 & 17.3 & 17.5 & 17.5 \\
\hline$>11$ & 18.2 & 18.4 & 18.5 & 18.5 & 19.3 & 19.9 \\
\hline \multicolumn{7}{|l|}{ Proportion (\%) of all ambulatory care visits to: } \\
\hline Generalists & 45.8 & 45.1 & 44.9 & 44.5 & 44.4 & 44.1 \\
\hline Internists & 16.9 & 16.7 & 16.6 & 16.4 & 16.6 & 16.7 \\
\hline Other specialists & 31 & 31.5 & 30.8 & 30.7 & 30.7 & 30.5 \\
\hline $\begin{array}{l}\text { Physicians from hospital outpatient services } \\
\text { (specialty unknown) }\end{array}$ & 6.3 & 6.8 & 7.8 & 8.4 & 8.3 & 8.7 \\
\hline
\end{tabular}

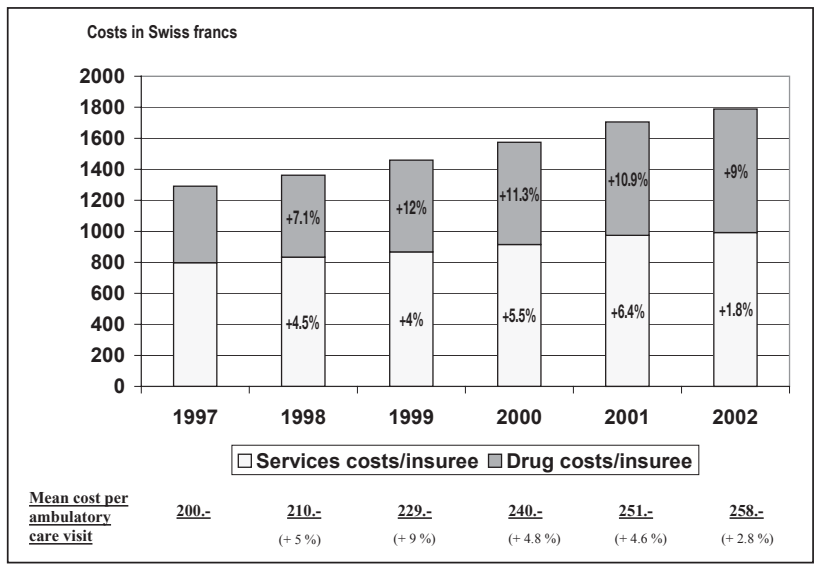

Figure 1 Evolution of a ambulatory care costs (mean costs/insuree/year), from 1997 to 2002

\section{Discussion}

This study explored patterns and trends of ambulatory care utilization of patients with almost no financial barriers to health care. In a demographically stable population of insurees, ambulatory care utilization was characterized by an increase in ambulatory care costs which was primarily due neither to a growth in the volume of physicians visits nor to an increase in physicians fees. Rather, the increase was essentially due to what was included in or prescribed during physicians' visits, particularly prescribed ambulatory care drugs. Unfortunately, whether the latter represented a higher number of drugs and/ or more expensive drugs prescribed remained unknown.
A complete data set of all insurees with minimal annual deductible from a sizeable insurance company, the large sample size and the availability of individual level data devoid of recall bias are important strengths of this study. However, some limitations have to be considered. Firstly, due to the scarcity of Swiss health care data and because little has been published on Swiss ambulatory care utilization (Etter \& Perneger 1997; Jeangros et al. 1999; Schellhorn et al. 2000; Martin et al. 1981), trends in utilization and costs components are difficult to analyze more precisely. Nonetheless, compared to the usually used aggregated data, we had additional information on the number of physicians encounters and the type of providers seen. Secondly, insurees who had annual health care costs below the minimal deductible were considered to have no utilization if they did not send their bills to the health insurance plan. As the minimal deductible was low, underestimation of ambulatory care utilization was minor. In addition, hospitalization and medical visit figures similar to ours were described in the 2002 Swiss Health Survey (Office fédéral de la statistique 2003). Finally, we cannot ascertain generalization of our results to the Swiss population having minimal annual deductible, as we do not know how similar other health plans insurees are to the insurees included in this study. Nevertheless, the health insurance company considered is one of the four major Swiss health insurance companies with a yearly number of insurees of 1 million, and its insurees and the Swiss population show very close age-sex compositions. Growth in ambulatory care costs in Switzerland (Sturny 2004), can be due to increases in the price, volume or change 
of mix of prescribed drugs and/or services, or in a combination of them. Drug prices, that rose by $48 \%$ from 1998 to 2003 (Santésuisse 2004) could explain part of that growth, while in contrast, prices of other medical inputs (physicians fees, charges for X-rays, laboratory tests, ...) did not significantly change during those years and medical care inflation remained modest. According to our data, the progression of the volume of ambulatory care visits was marginal and was unlikely to explain rising ambulatory health care costs. However, the volume of what was included in or prescribed during a physician's visit increased, and the type of providers visited changed, which may both have contributed to the evolution of costs. A higher number of drugs prescribed could also be a possibility. Unfortunately, a change in the mix of prescription of drugs or services cannot be excluded or confirmed due to the limitations of our data set, but more prescriptions of services and drugs is likely in a context of continuing development of medical care technology, expending choices and recent changes in drug therapy and/or therapeutic aggressiveness.

Aging of the population as a possible major cause for the continuing rise in ambulatory care consumption in our sample may be wisely ruled out as it was demographically stable. Increased physicians' density could result in rising demand from patients (Domenighetti \& Pipitone 2002), even more if they face little barriers to health care, or in physician-induced demand, especially in a system of fee-for-service payment shown to be a predictor of health care utilization (Greenfield et al. 1992). Results of physician-induced demand studies are inconsistent. In Switzerland, despite the existence of crosssectional associations between physicians' density and health care costs (Domenighetti 1998; Domenighetti \& Casabianca 1995), variations in costs do not seem to be correlated to physicians' density (Abrahamsen et al. 2005; Horisberger et al. 2004). Technologic advances and innovation, which spread largely and are usually associated with increased costs (Bodenheimer 2005b), are very likely to be also responsible for part of the growth in Swiss health spending in a period of low variation in the volume of ambulatory care consultations.

In conclusion, information on time trends in ambulatory care can improve our understanding of that component of the health care system. It may also assist in the formulation of health policies related to ambulatory care. In the future, it should however be combined to more detailed systematic data collection. In the meantime, in a health care system that abruptly institutes new regulations, available data should be used. They actually allow us to detect ambulatory care trends: the intensification of ambulatory care visits, not in terms of number of visits but of what is subsequent to them, should be looked upon more carefully.

\section{Acknowledgements}

We are grateful to K. Beck and S. von Rotz, from the CSS Insurance in Luzern, Switzerland, for providing the original data of our study.

\section{Zusammenfassung}

Das Verständnis der Inanspruchnahme ambulanter Behandlungen in der Schweiz bei minimaler Franchise.

Fragestellung: Welches sind die Trends bei der Inanspruchnahme ambulanter Behandlung in der Schweiz, wenn für Leistungsbezüger praktisch keine finanziellen Grenzen bestehen.

Methode: Beobachtungsstudie von Versicherungsdaten. Berücksichtigt wurden Erwachsene mit minimaler Franchise. Inanspruchnahme und Kosten ambulanter Behandlung wurden für die Jahre 1997 bis 2002 gemessen.

Resultate: Die durchschnittlichen ambulanten Behandlungskosten/versicherter Person stiegen von CHF1292.- auf CHF 1790.-, was mit einer grösseren Steigerung bei den Medikamentenpreisen $(+61.7 \%)$ als bei den Leistungskosten (+24.3\%) einher ging. Der Anteil an Besuchen bei Allgemeinpraktikern ging zurück, während die ambulanten Spitalbesucher anstiegen.

Schlussfolgerungen: In einer demographisch stabilen Population von Versicherten konnte der Anstieg bei den ambulanten Behandlungskosten weder auf eine grössere Zahl an Arztbesuchen noch auf höhere Arztkosten pro Behandlungseinheit zurückgeführt werden, sondern darauf, was in der Behandlung enthalten war oder verschrieben wurde. 
Résumé

Compréhension de l'évolution du recours aux soins ambulatoires lorsque la participation financière personnelle est minimale

Objectifs: Examiner les tendances dans le recours aux soins ambulatoires lorsque les individus ne rencontrent presque pas de barrières financières pour accéder aux soins de santé.

Méthodes: Etude observationnelle de données provenant des assurances, incluant les adultes ayant une franchise minimale. Les visites et les coûts des soins ambulatoires ont été mesurés de 1997 à 2002.
Résultats: Les coûts moyens des soins ambulatoires par assuré ont augmenté de 1292.- à 1790.-CHF, ce qui correspond à une augmentation plus importante des coûts des médicaments $(+61.7 \%)$ que des services $(+24.3 \%)$. La proportion des visites aux médecins généralistes a diminué tandis que les visites aux services hospitaliers ambulatoires ont augmenté.

Conclusions: Au sein d'une population d'assurés démographiquement stables, l'augmentation des coûts des soins ambulatoires n'était due ni à l'augmentation des visites médicales, ni à l'augmentation des tarifs médicaux par acte, mais à ce qui était inclus ou prescrit durant ces visites.

\section{References}

Abrahamsen Y, Hartwig J, Schips B (2005). Empirische Analyse des Gesundheitssystems Schweiz. Zürich:Vdf-Hochschulverlag an der ETH.

Bodenheimer T (2005a). High and rising health care costs. Part 1: seeking an explanation. Ann Intern Med 142: 847-54.

Bodenheimer T (2005b). High and rising health care costs. Part 2: technologic innovation. Ann Intern Med 142: 932-7.

Bodenheimer T (2005c). High and rising health care costs. Part 3: the role of health care providers. Ann Intern Med 142: 996-1002.

Domenighetti G, Pipitone E (2002). Induction de l'offre de prestations médicales par la demande. Primary Care 2: 241-5.

Domenighetti $G$ (1998). Médecine ambulatoire: principal facteur de coût et d'inflation à la charge directe des assurés? Méd et Hyg 56: 381-8.

Domenighetti G, Casabianca A (1995). Health care economics, uncertainty and physician-induced demand. Schweiz Med Wochenschr 125: 1969-79.

Etter JF, Perneger TV (1997). Introducing managed care in Switzerland: impact on use of health services. Public Health 641: 417-22.
Greenfield S, Nelson EC, Zubkoff M, et al. (1992). Variations in ressource utilization among medical specialties and systems of care. Results from the Medical Outcomes Study. JAMA 267: 1624-30.

Horisberger B, Schmid O (2004). Ärztestopp als Kostenbremse - Warum es Zeit ist umzudenken. Bulletin des médecins suisses 85: 887-94.

Jeangros C, Hausser D, Martin J (1999). Ambulatory medical care for the elderly in Switzerland. Soc Sci Med 31: 1085-92.

Martin J, Demierre G, Lehmann P, Paccaud F (1981). A general view of the ambulatory care sector: structural and functional study in the cantons of Vaud and Fribourg. Soz Praventivmed 26: 51-7.

Organization for Economic Co-operation and Development (2004). OECD health data 2004 a comparative analysis of 30 countries. Paris: OECD

Office fédéral de la santé publique (2004). Statistique de l'assurance-maladie obligatoire 2003. Berne: OFSP. http://www.bag.admin.ch/kv/statistik/f/2005/KV_2003_FR_v100105.pdf

Office fédéral de la statistique (2003). Enquête suisse sur la santé 2002: premiers résultats. Neuchâtel: OFS.

Polikowski M, Santos-Eggimann B (2002). How comprehensive are the basic packages of health services? An international comparison of six health insurance systems. J Health Serv Res Policy 7: 133-42.
Santésuisse (2004). Plus forte hausse des coûts en 2003. Berne: Santésuisse. http://www.santesuisse.ch/datasheets/files/200405171736330.pdf

Schellhorn M, Stuck AE, Minder CE, Beck JC (2000). Health services utilization of elderly Swiss: evidence from a panel data. Health Economics 9: 533-45.

Sturny I (2004). Comparaison 1999-2003 des coûts de la prise en charge en milieu hospitalier et ambulatoire en Suisse: analyse des dépenses des assureurs-maladie (AOS) effectuée sur la base du pool de données de santésuisse. Neuchâtel: Observatoire suisse de la santé.

Address for correspondence

Peytremann Bridevaux, Isabelle, MD, MPH

Health Services Research Unit

University Institute of Social and

Preventive Medicine

17 Bugnon

CH-1005 Lausanne

Switzerland

Phone: 41213147284

Fax: 41213147373

e-mail: Isabelle.Peytremann-Bridevaux@ hospvd.ch 